\title{
Occasions of Presenting Royal Gifts during the New Kingdom
}

\author{
Aya Mahmoud Farhan ${ }^{a}$ \\ Mohamed Heragi Ahmed c, \\ , Ahmed Mohamed Aboelmagd ${ }^{\mathrm{b}}$, \\ a Researcher for Master Degree, Tourist Guidance Department, Faculty of Tourism and Hotels, Minia \\ University \\ b Professor, Tourist Guidance Department, Faculty of Tourism and hotels, Minia University \\ c Lecturer, Tourist Guidance Department, Faculty of Tourism and Hotels, Luxor university
}

\section{Keywords}

Gifts

Occasions

External relations

New Kingdom

\begin{abstract}
This paper will discuss the occasions of sending gifts to the king by the foreigners. This paper shows, also, that diplomatic gifts exchanged between equals kings were a significant tool used during New kingdom to maintain the peaceful relationships between Egypt and the other powerful kingdoms such as Mitanni, Khetta, Cyprus and Babylon. The vassals' rulers also presented gifts to the king in different occasions in order to show their submission to the legitimate ruler of Egypt, their lord .

The circumstances in which gifts were exchanged are diverse: the celebration of marriage arrangements, the ascension to the throne of a king, the combat of an alliance treaty, victory over an enemy, feasting, and the arrival of messengers.
\end{abstract}




\section{Introduction}

Egypt reached the apogee of its power, wealth and territory borders and obtained a time of international prestige in the New Kingdom (1550-1069 BCE), the last and greatest Empire Age of Ancient Egypt, as a result of several successful military campaigns, Egypt granted recognition and adulation of the conquered countries, and the northern conquest earned Egypt's rules entrance into a brotherhood of Great kings that was jealously guarded and open only to the most powerful rulers of the ancient Near East. The diplomatic mission that Thutmose III received from the kings of Cyprus, Assyria, Babylon, and Hatti while he was on campaign indicate his acceptance into the select club. Quite likely, each of these polities had a vested interest in foresting an alliance with a proven enemy of Mitanni. In the annals, the arrival of the diplomatic mission to meet the king and his army is noted together with an inventory of the greeting gifts each bore, tokens of the donor's respect and sincerity of intention. These greeting gifts often included minerals that were difficult to obtain both for the sender and the receiver .

Throughout the New Kingdom, several countries, kingdoms and cities presented gifts to the king in a largely yearly ceremony or during his annual visit to foreign countries. The diplomatic gifts exchanged between kings were a significant tool used to maintain the peaceful relationships between Egypt and the other powerful kingdoms such as Mitanni, Hittite, Cyprus and Babylon. Rulers and princes of several foreign cities in north and south, which were under the king's authority and control used to bring their gifts to the king in order to show their submission to the legitimate ruler of Egypt .

Although Egypt is perhaps better known for its several military campaigns, particularly during the New Kingdom (1550- 1069 BC.), friendly relations between states- what we can define as diplomatic relations- can be found throughout ancient Egyptian history. Diplomatic relations can be glimpsed in the evidence, both in Egypt and beyond, through gift exchange, diplomatic marriage, the correspondence delivered by envoys to rulers and perhaps even through state visits (Lisa , 2019).

The exchange of gifts was an important aspect of cementing the diplomatic relationship between the kings; the sending of gifts and gifts sent in return, reflected friendly relations. Such gifts take many forms from chariots and gold to silver and animals- and after being received, they were often ceremonially displayed before an assembled crowd to emphasize the king's status. Incorrectly displayed gifts, or those regarded as lacking in quality, resulted in angry letters being sent; such was the case with the Babylonian king, who complained Amenhotep III that the chariots he had sent to Egypt had been reviewed alongside those sent by vassals kings (Lisa , 2019).

Generosity and munificence were matters of great importance in gift exchanges between royal courts. Lavish provision of gifts for a royal brother contributed much to the prestige of the giver. It demonstrated the wealth and prosperity of his kingdom; it provided an exposition of all the material resources at his disposal. It was also a measure of his love for his royal brother. The more generous the gifts, the greater the love (Bryce, 2004).

According to the reciprocal system, the counter-gifts had to be offered not simultaneously but only on a later occasion, with an Egyptian mission to the court of 
the foreign gift-giver. Through this practice the Egyptian king appeared in his land always as a receiver of foreign gifts and never as a supplier of them. The ideological concept demonstrated during these ceremonies to the Egyptian audience was that of the king as a universal ruler who received contributions from all over the world (Panagiotopoulos , 2001)

\section{Discussion:}

\subsection{Court Events as a means of Royal Prestige}

Presenting the gifts to the king was considered a great public event. The tomb scenes of the 18th dynasty gave an evident that this event was organized as a triumphal procession and that foreign princes and ambassadors were invited to attend this event as witnesses of the king's glory and power (Kemp, 2000) ${ }^{1}$. During the late of New Kingdom, it was the costume to invite foreign rulers, city governors, and ambassadors to royal festivals to produce an impact on the foreign community (Roth ,2005) ${ }^{2}$

Letters between Amenhotep III and the ruler of Babylonia give an insight into this custom and into the diplomatic controversies it could ignite' :As for your (i.e., the Babylonian king) saying to me, "He (i.e., the king of Egypt) put my chariots among the chariots of the mayors. You (i.e., the king of Egypt) did not review them separately. You humiliated them before the country where you are. You did re<view> (them) separately".

The complaint quoted in Amenhotep's letter is part of a former message by the Babylonian king on the distribution of foreign gifts and tribute during an official show at the Egyptian residence: it seems that the complaint was based on a general silent agreement about distinguishing diplomatic gifts sent by political allies from regular taxes levied from city-states and kingdoms under the control of a superpower (Liverani, 1990). Thus, public display of goods served as power display within the foreign political community (Jansson, 2004) ${ }^{3}$. So, the Babylonian king felt offended that his gift of chariots was lumped together with those sent by Egyptian vessels (Opladen, 1994) ${ }^{4}$.

\footnotetext{
${ }^{1}$ Kemp. B. J " The Window of Appearance at El-Amarna, and the Basic Structure of This City," in, JEA 62, 1976,99; El Menshawy. S. "Pictorial evidence depicting the interaction between the king and his people in ancient Egypt." BAR INTERNATIONAL SERIES 909 (2000): 84. For illustration, see, for instance, the presentation of the foreign tribute in the tomb of the vizier Rekhmire from the time of Tuthmosis III, Davies. N. G, The tomb of Rekh-mi-Rē at Thebes, Vol. 1, 1944, 17-30, Vol. II, Pl. XVII-XXIII. For a more general interpretation of these depictions see, EL-Din M. Shaheen, Historical significance of selected scenes Involving Western Asiatics and Nubians in the private Theban Tombs of the XVIIIth Dynasty, PH.D, University of Pennsylvania, 1988; S. Wachsmann, Aegeans in the Theban Tombs, OLA 20, 1987, 4-26; and M.K. Hartwig, Tomb Painting and Identity in Ancient Thebes, 1419-1372 BCE, MonAeg 10, Tumhout 2004, 73-76, with references on p.75

2 Roth. S, Jn schönem Frieden befriedet und in schöner Brüderschaft verbrüdert1 '. Zu Motivation und Mechanismen der ägyptisch-hethitischen diplomatischen Kontakte in der Zeit Ramses 'II, in, D. Prechel, Motivation und Mechanismen des Kulturkontaktes in der späten Bronzezeit, Eothen ; 13, Florence 2005, 179- 227. ${ }^{3}$ C. Jonsson, Diplomatic signaling in the Amarna letters, in: Cohen/ Westbrook (eds.), Amarna Diplomacy, 191204, in 194, he compares the exchange of gifts in the Amarna Age with the handshake between representatives of today's superpowers and understands both actions as 'visual signs of friendly relations' and 'conciliatory symbols'

${ }^{4}$ This is not the only case that the Egyptian king was reproached for presenting the political reality in a manner which did not accord with the pretence of equality which characterised Egypt's diplomatic relations with other states: the Hittite king expressed his annoyance about the way Ramesses II recollecting the ending of the war between both states in his own country, see E. Edel, Die agyptische- hethitische korrespondenz aus Boghazkoi in babylonischer und hethitischer sprache, ARWAW 77, Opladen 1994, Vol. I, 58-64, Vol. II 95-121
} 
The mutual invitation among allies' rulers to participate in royal celebrations and festivals, in person or thought ambassadors, seems to have been a major issue in the diplomatic relations during the New Kingdom. Neglecting those conventions could result in political tensions between the superpowers ${ }^{5}$. This is shown by another letter sent to Amenhotep III by the king of Babylonian :

When you celebrated a great festival, you did not send your messenger to me, saying, "Come to eat and drink". Nor did you send me my greeting-gift in connection with the festival. It was just 30 minas of gold that you sent me. My gift does not amount to what I have given you every year (Liverani, 1990)

One way of keeping diplomatic relations or coalitions alive was a state visit at the ally's residence. These invitations, similar to the state dinners of modern days, were paraphrased as 'taking a meal together and having strong beverages'; it is evident that commensality had a strong ritual aspect, especially among foreign parties ${ }^{6}$ (See 2004). That a state leader would take the trouble to set out on a journey of several months in order to visit an ally's residence in a far-way country, however, probably occurred very rarely. The visual practice was to send ambassadors and messengers who conveyed to their hosts the greetings and the respect of their lords by delivering exotic gifts ${ }^{7}$. The value of these gifts in terms of precious materials and artistic expertise seems to have substantially contributed to a king's political prestige in his own country and abroad. Consequently, the desire to increase one's own glory and recognition in all parts of the contemporary Mediterranean led to increasing expenses, since the political and cultural balance between powers demanded equal wealth and pomp (Raymond, 2000).

During a public reception of diplomatic gifts, the court and its guests were invited to take a close look at the deliveries at the moment when they arrived. If the goods turned out to disappoint expectations, a state leader risked making a fool of himself in the presence of the entire court, including foreign princes and the ambassadors. Thus, the ruler had to avoid any less of prestige during a public ceremony, this pressure was passed on to the king's delegates, who were responsible for the quality and the size of the products delivered. The public function of reception platforms and the windows of appearance increased the psychological impact on the performers 'side even more; the vast public spaces provided room for a large number of participants, and the ceremony had to be staged adequately and spectacularly: separated and elevated from the rest of the spectators, the king and his family presided over the show as addresses, accompanied by the royal body guard and high officials; embassies with caravans of goods operated as the motor of the event, while courtiers, and foreign guests as well as the broader public were the eyewitnesses of the miracles that took place at the Egyptian court.(El Menshawy , 2000)

\footnotetext{
5 According to Liverani, M. "the great power club" in: Cohen/ Westbrook (eds.), Amarna Diplomacy, 15-27, this form of diplomatic contact is, together with hospitality, intermarriage, exchange of gifts, and mutual recognition of status, characteristic of international relations that work on the basis of interpersonal relations and can, therefore, be compared to relations among families, clans, or villages

6 See R. Cohen, Intelligence in the Amarna letters, in: Cohen/ Westbrook (eds.), Amarna Diplomacy, 89. And L. Green, "Some thoughts on ritual banquets at the court of Akhenaten and in the Ancient Near East, in: G.N. Knoppers/ A. Hirsch (eds.), Egypt, Israel, and the Ancient Mediterranean World. Studies in honor of Donald B. Redford, PA 20, 2004, 203-222, where she basically concentrates on banquets that serve to establish and reinforce relations of unequal social power (p.208) especially during the Amarna period

${ }^{7}$ On this diplomatic convention see Zaccagnini, C, "The Interdependence of the great powers" in: Cohen/ Westbrook (eds.), Amarna Diplomacy, 151
} 


\section{2 . The compact of an Alliance Treaty}

The compact of an alliance treaty may constitute a reason for sending gifts between the parties of the treaty. The link between gifts and alliance is naturally very close in the extent to which accepting gifts from subjects implies the need to establish a personal bond between the parties; so, after a peace treaty between parties that were hostile to each other they began to exchange gifts between them. Even if there are not documents that mentions exchanges of gifts contextual to the stipulation of an alliance treaty, we are informed of gifts sent immediately after the agreement (Zaccagnini, 1973). After the peace treaty between Ramesses II and Hittites, royal gifts were sent from the Hittite king to the king Ramesses II and his foreign wife, the daughter of the Hittite king ${ }^{8}$.

\subsection{Celebration of Victory}

The successful military campaign could give the winner the inspiration to offer gifts from the subjects with whom he was in friendship, probably to publicize his war enterprise, in addition to gain fame and consideration in the eyes of his peers and increase his prestige on the international political horizon .(Zaccagnini, 1973)

On the other hand, the news of a victory could have been a reason for congratulation by the kings, who took this opportunity to send gifts to their collagenous .(Zaccagnini, 1973)

The political intent of the announcement made by Tusratta ${ }^{9}$ to Amenhotep III of the defeat inflicted on the Hittites, the king of Mitanni, eager to make a good impression in the eyes of the kings, proudly reports of his military successes and sends part of the spoils of the country of Hatti to the king of Egypt as gifts ${ }^{10}$.

The Annals of Thutmosis III often relate the offer of gifts by foreign powers (Assyria, Babylon, Hatti, and Alasiya) after his victory in Asia ${ }^{11}$.

\subsection{Wedding Celebrations}

The gifts sent to the king in the celebration of this especial occasion including the dowry sent with the foreign bride of the king. Besides the female servants who usually accompanied the foreign princess from her homeland to Egypt ${ }^{12}$, the foreign bride brought all her personal items for her daily use from cloth to jewelry and furniture 13 .

The foreign princess had to bring astonishing and valuable royal marriage gifts from her homeland to the king. Although these royal marriage gifts varied according

\footnotetext{
${ }^{8}$ Stela Louvre C.284, KRI, II, p. 285:6-7.

${ }^{9}$ Tusratta was the Mitannian king at the end of the reign Amenhotep III and throughout the reign of Akhenaten

${ }^{10}$ EA 17: 36-38

${ }^{11}$ Assur: Urk IV 668: 3, 6; 671 : 8; $701: 6$ ( ? ) ; Babilonia: Urk IV 700: 16; Hatti: Urk IV 701 : 11 ; 727: 13; Alasiya: Urk IV 707: 16; 719: 13; 724: 10; Gifts to Amenhotep II are offered by the king of Mitanni, the king of Hatti and the king of Babylon, at the end of the third Asian campaign: Urk IV 1309, Urk IV 1326

12 Thutmosis III mentioned that the Retenu princess came to Egypt accompanied by 30 servants. Then later and during the reign of Amenhotep III, another foreign princess came with 317 women. Urk IV, pp. 669:1-3; 1738:614

${ }^{13}$ A list of all the items daughter of Mitanni king Tushratta brought with her are found in the Amarna archive. It is a long list including everything that the future queen would need for her daily life. Moran, EA 25, pp.72-84
} 
to the country from which the foreign bride came, there were some fundamental items to be included, especially chariots with their accessories, horses and servants ${ }^{14}$. Other invaluable items such as jewelry, cloth, furniture, appliances, oil, perfumes and more were brought by the foreign bride to be presented to the king in the celebration of his marriage. King Ramesses II listed the marriage gifts that the daughter of the Hittite king brought with her: "He (the Hittite king) allowed his eldest daughter to come, in front of her precious gifts (inw) of gold, silver, a great amount of bronze, serfs, horses, cattle, goats and sheep of ten thousand." 15 There can be doubt that marriage gifts had, beyond their political and symbolic content, an enormous economic significance for both parties .(Panagiotopoulos , 2001)

\subsection{Message delivery}

Message could not be sent without a greeting-gift that would prompt the start of communication between the royal courts. It also functioned as an element of induction, a situation that consisted in sending a small amount of the product that is expected to be exchanged in a greater quantity. There was as well a 'rejection gift' mechanism, which consisted in sending a small amount of the required good back to its sender, indicating in this way a rejection of proceeding with the exchange. (Pfoh, 2016)

Amarna Letters show that every dispatch from the royal correspondents was accompanied by a gift (Aldred, 1970) except in one certain case concerning the King of Babylon, Burnaburiash, is quite explicit that since the king has not sent him anything valuable by the hand of his envoy, he, in turn, has nothing precious to be sent to the king. That means they were sending gifts that had to be paid for by presents of equivalent worth. The value of such gifts is precisely stated, probably because the donors expected a return of equal value. The correspondences letters from Amenhotep III and Akhenaten reveal that they both sent rich gifts to their brother monarchs .(Aldred, 1970)

These gifts varied to include different types of materials and substances based on the place from which they were sent to the king. For instance, copper was the most important component sent from king of Cyprus (Alasiya), lapis lazuli from king of Babylon, silver from Hittite and valuable metal crafts including jewelry and vessels inlaid with precious stones from Mitanni ${ }^{16}$. In addition, other common items such as horses, chariots, weapons and servants were sent from various foreign countries to the Egyptian king ${ }^{17}$.

\section{Conclusion :}

- The diplomatic gifts exchanged between kings were a significant tool used to maintain the peaceful relationships between Egypt and the other powerful kingdoms such as Mitanni, Hittite, Cyprus and Babylon. Rulers and princes of several foreign cities in north and south, which were under the king's authority

\footnotetext{
${ }^{14}$ These specific items were included in the Amarna letters and Ramesside sources. They were among the items the Mitanni king sent to the pharaoh with his daughter. In another Amarna letter, the king ordered one of the foreign rulers to send his daughter with a marriage gift included " 20 of the best servants, silver, chariots, best horses.” Moran, EA 22; 97, pp. 51-61; 171-2; KRI, II, pp.83; 247:1-9; 257: 11-12

${ }^{15}$ KRI, II, pp. 247:1-9; 257: 11-12

${ }^{16}$ Moran, Amarna letters, EA 2; 8-11; 0i917; 19-21; 27; 29; 33-5; 37; 41, pp. 6, 16- 22; 41- 50; 86-99; 104-115

${ }^{17}$ See, Moran, Amarna letters
} 
and control used to bring their gifts to the king in order to show their submission to the legitimate ruler of Egypt, their ruler.

- Generosity and munificence were matters of great importance in gift exchanges between royal courts.

- Presenting the gifts to the king was considered a great public event. The presentation of a wide variety of gifts to the king was a repetitive subject in private tombs, especially during the New Kingdom. In this type of scene, the king usually is depicted receiving foreign gifts from various foreign countries. A unique depiction of this glorious and solemn event is from the tomb of the Overseer of the Double Treasury of Akhenaton, Meryre II ${ }^{18}$.

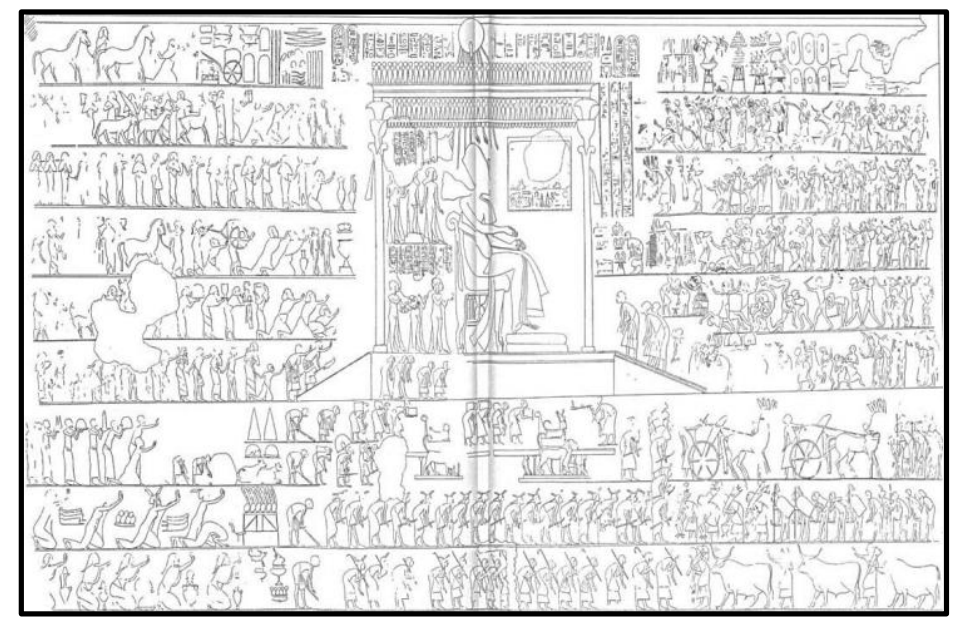

(Fig. 1) The King Receiving Gifts of the Foreign Lands from the Tomb of Meryre II $^{19}$

In the center, the king appears enthroned on an elevated platform reached by two sets of stairs (one on each side) and accompanied with the royal family. In six registers ${ }^{20}$, in front and behind him, foreigners from the southern and northern foreign countries and cities are depicted bearing their gifts to be presented to the king with illustrations of their gifts in the topmost register. In front of the king, the gifts of the southern countries include gold (raw and rings), leather, and ostrich feathers. Horses and weapons are depicted behind the king as exemplification of the most important gifts of the northland. The gifts included different types of precious metals, animals, weapons and slaves. In addition to the gift bearers, there are individuals depicted while performing some sportive activities in front of the king including wrestling, singlesticks and boxing (the first two registers in front of the king) ${ }^{21}$. In the three registers below the king's pavilion, more foreigners are depicted bearing their gifts. This could be a depiction of the crowd waiting to get into the king's presence. It is

\footnotetext{
${ }^{18}$ For the first time, the date of this event is included in the text accompanied the scene, it is year 12 of King Akhenaton. The date is recorded in this tomb and also in the tomb of another contemporary official, the Overseer of the Treasury Huya. The reason for including the date here is not clear, was it because the two officials were promoted in this year to hold their high positions associated with overseeing the treasury? Was year 12 their first time to attend the presentation of the foreign gifts to the king in their new positions

${ }^{19}$ RTA, II, pl. XXXVII, 38

${ }^{20}$ The different groups of foreigners are labeled unlike Rekhmire's scene. See, Davies. N.de G, Painting from the Tomb of Rekh-mi-Re at Thebes, Publications of the Museum of Art, Egyptian Expedition10, New York 1935. pls. XXIX- XXXV

${ }^{21}$ Similar sport scenes are depicted in Medinet Habu, in the frieze below the Royal Palace's window of appearance. It seems that such sportive actives used to be performed in the presence of the king during the celebration of special occasions. Breasted, J.H, Medinet Habu Reports: I the Epigraphic Survey 1928-31, Oriental Institute Communications, Chicago 1931.
} 
evident from this scene (beside Huya's depiction of the same subject) ${ }^{22}$, that this magnificent event did not take place at the Royal Palace ${ }^{23}$.

\footnotetext{
${ }^{22}$ The king was not depicted in this scene and group of building were depicted including an elevated platform and another three structures two of them contain supplies of food and provisions. RTA, III, pl. 14; Kemp, B.J, Ancient Egypt : Anatomy of a Civilization, London \& New York 1989, 286-7.

${ }^{23}$ Two different locations were suggested for the tribute hall. The first is the building in the northern wall of the great temple at Amaran. The second is group of structures located in the desert; in the area between the northern palace and northern toms known as "Desert Alters". Pendlebury,J.D.S., The City of Akhenaten, Part III, The Central City and the Officials Quarters, Egypt Exploration Society 44, London 1951, .22-5, pl. X; B.J. Kemp, 287.
} 


\section{Bibliography}

Aldred, "The foreign gifts offered to Pharaoh", in JEA 56, 1970.

Breasted. J.H, Medinet Habu Reports: I the Epigraphic Survey 1928-31, Oriental Institute Communications, Chicago 1931.

Bryce. T, Letters of the Great Kings of the Ancient Near East: The Royal Correspondence of the Late Bronze Age, Routledge, 2004.

Davies. N. G, The tomb of Rekh-mi-Rē at Thebes, Publications of the Museum of Art, Egyptian Expedition10, New York. Vol.I, Vol II.

Edel, Die agyptische- hethitische korrespondenz aus Boghazkoi in babylonischer und hethitischer sprache, ARWAW 77, Opladen 1994, Vol. I, Vol.II.

El Menshawy. S. "Pictorial evidence depicting the interaction between the king and his people in ancient Egypt." BAR INTERNATIONAL SERIES 909 (2000).

EL-Din M. Shaheen, Historical significance of selected scenes Involving Western Asiatics and Nubians in the private Theban Tombs of the XVIIIth Dynasty, PH.D, University of Pennsylvania, 1988.

Green. L, "Some thoughts on ritual banquets at the court of Akhenaten and in the Ancient Near East, in: G.N. Knoppers/ A. Hirsch (eds.), Egypt, Israel, and the Ancient Mediterranean World. Studies in honor of Donald B. Redford, PA 20, 2004.

Hartwig. M.K, Tomb Painting and Identity in Ancient Thebes, 1419-1372 BCE, MonAeg 10, Tumhout 2004.

Jonsson. C, Diplomatic signaling in the Amarna letters, in: Cohen/ Westbrook (eds.), Amarna Diplomacy, 191-204.

Kemp. B. J "The Window of Appearance at El-Amarna, and the Basic Structure of This City," in, JEA 62, 1976.

Kemp. B.J, Ancient Egypt: Anatomy of a Civilization, London \& New York 1989.

Lisa. S. K. All Things Ancient Egypt: An Encyclopedia of the Ancient Egyptian World [2 volumes], ABC-CLIO, 2019.

Liverani. M, "the great power club" in: Cohen/ Westbrook (eds.), Amarna Diplomacy, 15-27.

Liverani. M, Le Lettere di el-Amarna II, Paideia, 1999.

Liverani. M, Prestige and Interest. International Relations in the Near East ca. 16001100 B.C, padua 1990.

Moran. W, The Amarna Letters, The Johns Hopkins University, 2000.

Panagiotopoulos D, "Keftiu in Context: Theban Tomb-Paintings as A Historical Source", in Journal of Archaeology 20, 2001.

Pendlebury. J.D.S, The City of Akhenaten, Part III, The Central City and the Officials Quarters, Egypt Exploration Society 44, London 1951.

Pfoh. E, Syria-Palestine in the Late Bronze Age: An Anthropology of Politics and Power, Routledge, 2016.

Roth. S, Jn schönem Frieden befriedet und in schöner Brüderschaft verbrüdert1 '. Zu Motivation und Mechanismen der ägyptisch-hethitischen diplomatischen Kontakte in der Zeit Ramses 'II, in, D. Prechel, Motivation und Mechanismen des Kulturkontaktes in der späten Bronzezeit, Eothen ; 13, Florence 2005, 179- 227.

Stela Louvre C.284, KRI, II, p. 285:6-7.

Wachsmann. S, Aegeans in the Theban Tombs, OLA 20, 1987.

Zaccagnini. C, "The Interdependence of the great powers" in: Cohen/ Westbrook (eds.), Amarna Diplomacy.

Zaccagnini. C, Lo scambio dei doni nel Vicino Oriente durante i secoli XV-XIII, Centro per le antichità e la storia dell'arte del Vicino Oriente, 1973. 